ENTREPRENEURSHIP AND SUSTAINABILITY ISSUES

ISSN 2345-0282 (online) http://jssidoi.org/jesi/ 2020 Volume 8 Number 1 (September)

http://doi.org/10.9770/jesi.2020.8.1(16)

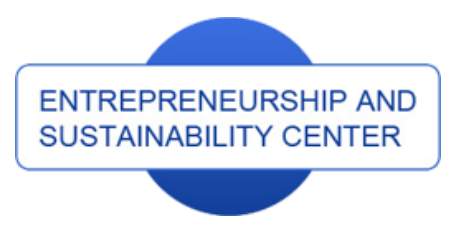

Publisher

http://jssidoi.org/esc/home

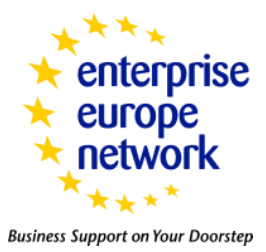

CASPA

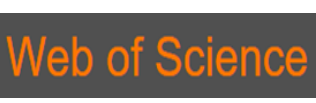

Clarivate
Analytics

\title{
ENERGY INFRASTRUCTURE AND FOREIGN DIRECT INVESTMENT IN CHINA
}

\section{Hameed Khan ${ }^{1}$, Imrab Shaheen ${ }^{2}$, Masood Ahmad ${ }^{3}$, Elmin Bakhshaliev ${ }^{4}$, Hashmat Ullah Khan ${ }^{5}$, Asif Kabir ${ }^{6 *}$}

\author{
${ }^{1}$ School of Economics, Jilin University, Changchun 130012, Jilin, China \\ ${ }^{1}$ Department of Economics, Kohat University of Science \& Technology, Kohat 26000, Pakistan \\ ${ }^{2}$ Department of Public Administration, University of Kotli, Azad Jammu and Kashmir, Kotli 11100, Pakistan \\ ${ }^{3}$ Lee Kuan Yew School of Public Policy, National University of Singapore, Singapore \\ ${ }^{4,5}$ School of International \& Public Affairs, Jilin University, Changchun 130012, Jilin, China \\ ${ }^{6}$ Department of CS\&IT, Faculty of Computing and Engineering, University of Kotli, Azad Jammu and Kashmir, Kotli 11100, \\ Pakistan \\ E-mails: ${ }^{1}$ hameed.qec@gmail.com $;{ }^{2}$ imrabs@yahoo.com $;{ }^{3} \underline{\text { e0009120@u.nus.edu }} ;{ }^{4}$ ebro_91@mail.ru ; \\ 5hashmat.kpk@gmail.com ; ${ }^{6}$ asif.kabir@uokajk.edu.pk
}

Received 10 January 2020; accepted 30 June 2020; published 30 September 2020

\begin{abstract}
China's integration into the world economy, and maintaining its rapid economic growth, demand more energy with a prominent concern of reducing carbon footprints. Keeping in view the shortcomings in previous studies, we investigate the relationship between energy infrastructure and foreign direct investment in China in the framework of the ARDL and VECM approaches. We found that energy positively affects FDI, while the reverse effect does not hold. FDI does not affect the energy sector. Policy implications can be drawn from this study, such as technological diffusion from FDI to enhance energy efficiency and reduce carbon footprints.
\end{abstract}

Keywords: Energy consumption; FDI; ARDL

Reference to this paper should be made as follows: Khan, H., Shaheen, I., Ahmad, M., Bakhshaliev, E., Khan, H.U., Kabir, A. 2020. Energy infrastructure and foreign direct investment in China. Entrepreneurship and Sustainability Issues, 8(1), 233-248. http://doi.org/10.9770/jesi.2020.8.1(16)

JEL Classifications: O47, F21, C22

\section{Introduction}

Excessive energy demand accompanies China's rapid economic growth. China has been given the blessing and the curse of being one of the largest energy consumers and was growing rapidly over the last few decades. Some of the drawbacks of its excessive demand for energy include emissions and carbon footprint. To take into account 


\section{ENTREPRENEURSHIP AND SUSTAINABILITY ISSUES}

ISSN 2345-0282 (online) http://jssidoi.org/jesi/

2020 Volume 8 Number 1 (September)

http://doi.org/10.9770/jesi.2020.8.1(16)

the issues of greenhouse emissions and maintain sustainable growth, China is making conscious efforts to increase the proportionality of clean energy in its energy mix.

Similarly, the massive inflow of foreign direct investment (FDI) in China is a marvelous phenomenon the world sees during the last three decades. The opening up policy made China the fourth largest destination for foreign investments with total FDI stock, USD 1769 billion in the year 2019 (UNCTAD 2019). This work explores the relationship between energy and FDI in China. The relationship between FDI and energy infrastructure, though necessary for policy concerns, is not studied. Previous literature mainly focused on the emission and growth enhancing aspects of energy consumption but ignored the foreign investment perspective.

Several factors affect foreign direct investment. Foreign firms make destination those countries with large market size (Bevan and Estrin 2004; Flores and Aguilera 2007; Bhaumik and Co 2011), better institutional quality (Islam et al. 2020; Wei 2000; Chakrabarti 2001; Blonigen, Ellis, and Fausten 2005) (Wei 2000; Chakrabarti 2001; Blonigen, Ellis, and Fausten 2005), natural resources (Deng 2004; Buckley et al. 2007; Kang and Jiang 2012), technology (Tihanyi and Roath 2002; Buckley et al. 2007; Kang and Jiang 2012), taxes (Blonigen and Davies 2004; Dharmapala and Hines 2009; Bilgili, Tülüce, and Doğan 2012; Azémar and Desbordes 2013), and trade openness (Wheeler and Mody 1992; Doytch and Eren 2012; Nagano 2013). However, for the first time, we explore the relationship between energy and FDI.

Foreign firms choose those countries as a destination where they find better energy infrastructure. Energy can leapfrog the production stages and enhances the productivity and efficiency of firms through various channels. For instance, ICT (information and communication technology) requires energy and creates information flow, which indirectly reduces time, distance, and costs of firms. Similarly, transportation sector requires energy, which indirectly reduces delivery times. Therefore, almost all the activities of firms are linked with energy. Therefore, it is assumed here that foreign firms choose those countries as their investment destination where they find better energy facilities.

The rapid development of China's economy demands a large amount of energy. In this regard, coal is the main energy source that drives more than half of the Chinese economy. China plans to build more power plants around the coalfields in its western regions. It wants to convert coal into electricity and then let the power grid carry it to the east, with 70 percent of the country's population and over 80 percent of its economy. Similarly, China imports around sixty percent of the oil that it consumes. It was the world largest oil importer in 2014, but it has been doing a lot to make sure its energy consumption across a range of fuels. That comes with significant benefits and some significant drawbacks, one of which is trying to procure enough energy to keep its rapid economic growth going. Coal is the primary position in China's energy structure, and it is essential to use coal efficiently. The use of traditional fossil fuels is causing enormous environmental damage. Therefore, China's coal demand falls back due to the fact that growing energy needs are increasingly met by renewables, natural gas, and electricity.

Previous studies focus on the impact of energy consumption on economic growth and other macroeconomic variables. Moreover, the majority of the previous literature discusses the environmental effects of energy. Similarly, more studies focused on cross-country analysis. We, for the first time, contribute the existing literature by examining the relationship between FDI and energy infrastructure on a country level to have in-depth insight. Moreover, previous studies are based on a single specification and a single equation. The earlier literature ignores the institutional quality, which may affect the FDI and energy relationship in developing countries like China. We contribute the literature by using the ARDL and VECM approaches in a multi-specification framework, which means that we add additional variables in the baseline model. Similarly, we contribute to the earlier literature by adding an important variable, i.e., institutional quality. 


\section{ENTREPRENEURSHIP AND SUSTAINABILITY ISSUES}

ISSN 2345-0282 (online) http://jssidoi.org/jesi/

2020 Volume 8 Number 1 (September)

http://doi.org/10.9770/jesi.2020.8.1(16)

The rest of the study is divided into the following sections. Section 2 describes the stylized facts of energy infrastructure in China. Section 3 explains the theoretical framework. Section 4 shows the data and methodology. Section 5 reports empirical results. In section 6, we show the concluding remarks of the study.

\section{Energy production and consumption in China}

In this section, we show how energy is a driving force for the rapid economic development of China. Similarly, China faces challenges that must be overcome to keep the wheels of the country turning under pressure for the ever-greater need for environmental protection. Since the market-oriented reforms in the 1980s, China favored economic growth with an emphasis on having considerable investments in energy infrastructure

Coal is the dominant source of energy in China; therefore, the whole power system is always a pivoted around it. The coal consumption has been increased from 1.05 to 3.97 billion tons from 1990 to 2015 . The Gobi desert in the northwest China is producing over 100000 tons of high-quality coal with less sulfur. During 2016, coal made up $62 \%$ of China's total energy use. Since 2011, China consumed more coal than the rest of the world combined, where it provides three-quarters of the nation's energy needs. Therefore, many macroeconomic indicators rely on the coal industry in China. In 2014, China contributed to air pollution by $71 \%$, which is far more than the European Union and the USA with $32 \%$ and $31 \%$ emissions, respectively.

Hydroelectric power has become China's leading source of renewable energy production. Having a generation capacity of 22,500 MW, in the upper reaches of the Yangtze River, Three Gorges Dam is completed in 2012 at the cost of over $\$ 37$ billion. It is the world largest hydroelectric dam. Additionally, China has also constructed three energy-producing hydroelectric dams. From 2000 to 2015, China increased its hydroelectric energy-generation capacity by $408 \%$. As a result of the Three Gorges Dam and other projects, China became the world leader in hydropower in 2014.

However, abundant water resources are not found everywhere. The west of China is short of water but has plenty of sunshine. The power of the sunlight and the number of hours the sun shines make it an ideal site for solar photovoltaic (PV) energy. In the Gobi desert, more than 20 thousand mirrors bounce the light with high precision, which makes China a leading player in solar photovoltaic during the last decade. This way of generating electricity does not consume any fuel or discharged any emissions. China's currently installed solar power capacity exceeds 70 million kilowatts accounting for one-fifth of the world solar generation capacity. More and more ways to utilize solar energy may revolutionize China's supply of clean energy. China's rapid development shows genuine determination to change its energy structure.

There are other emission-free energy sources to be tapped into. China is one of the nations that have taken the lead in seeking renewable energy from the wind, where the giant turbines are a common feature of the landscape in many locations. Offshore wind, on the eastern coast of China, is looking more and more like the future of wind power. In 2012, the electricity generated by wind power accounted for just $2.1 \%$ of China's total consumption. China accounted for one-third of the global wind-energy capacity in 2015 . With a $10.5 \%$ increase from the previous year, in 2017, China's wind power capacity reached to 16,367 megawatts (MW).

In China, the progress of science and technology drives energy. On a remote peninsula in eastern China, the most advanced nuclear power unit in the world is being prepared to be put into operation. The nuclear reaction releases enormous heat, which is used to turn water into high-pressure steam. It drives the generators to generate electricity. The nuclear fuel's energy density is 2.5 million times that of coal. China generated 38,419 (MW) of energy with the help of 41 nuclear power reactors as of July 2018. In its 13th Five-Year Plan, the Chinese government planned to construct 40 new nuclear plants by 2020. Nuclear plants run on nuclear fission and the 


\section{ENTREPRENEURSHIP AND SUSTAINABILITY ISSUES}

ISSN 2345-0282 (online) http://jssidoi.org/jesi/ 2020 Volume 8 Number 1 (September) http://doi.org/10.9770/jesi.2020.8.1(16)

energy released by splitting atomic particles. The energy released in this way is compelling, but it also creates dangerous radioactive wastes. Though controversial, nuclear power is still in its various forms is the great hope for an endless reliable and clean source of energy.

China has important and unconventional shale gas resources. China is moving into its own offshore to produce more oil and gas. Historically, it has been challenging for China to develop deep-sea oil and natural gas resources, which become possible by the approach known as the power compensator system. Natural gas emits $60 \%$ less $\mathrm{CO}_{2}$ as compared to coal when it is efficiently combusted. The natural gas consumption reached to 240.4 billion-meter cubic meters during 2017, which makes $6.4 \%$ of China's total energy consumption. The energy consumption, by natural gas, is higher than the earlier decade. The Chinese government is committed to increase energy sources from natural gas by $10 \%$ to its total energy demand by the end of 2020 . With the advance of deepsea engineering technology, China has made a further step in acquiring resources from the oceans. The energy stored in deep-sea is beyond imagination.

Fig. 1 shows the energy consumption by sector in 2016. Industry (manufacturing sector) consumes more energy, which is $67 \%$. The household and transportation sectors consume $21 \%$ of the total energy. While, in the same year, the manufacturing sector FDI part is $32 \%$, services constitute a $66 \%$ portion in total FDI, and the primary sector (agriculture, fishing \& mining) counted for only $2 \%$ (www.stats.gov.cn). Therefore, a question may arise that what is the contribution of the energy sector in attracting FDI.

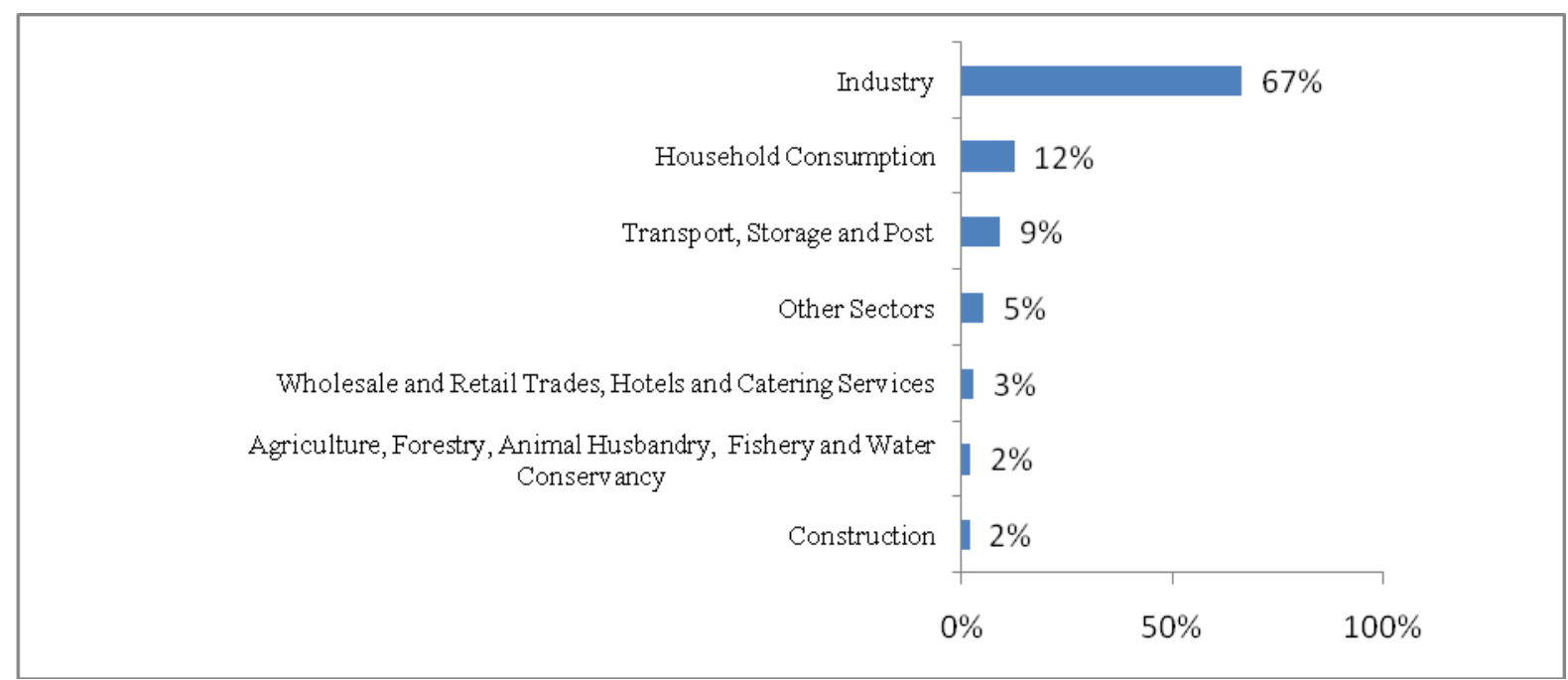

Figure 1. Energy consumption by sector in 2016 (\%). Source: China Statistical Yearbook 2018 (authors' calculations)

It can be seen in Table 1 that China has decreased the coal consumption from $76.2 \%$ in 1990 to $60.4 \%$ in 2017, while its coal production decreased from $74.2 \%$ in 1990 to $69.6 \%$ in 2017 . The clean energy consumption has been increased from 5.1\% to $13.8 \%$ during 1990 to 2017, and its production increased from $4.8 \%$ to $17.4 \%$ from 1990 to 2017. The figures highlighted the importance of renewables for China. 


\section{ENTREPRENEURSHIP AND SUSTAINABILITY ISSUES}

ISSN 2345-0282 (online) http://jssidoi.org/jesi/

2020 Volume 8 Number 1 (September)

http://doi.org/10.9770/jesi.2020.8.1(16)

Table 1. Consumption and production of energy and its composition (in percent)

\begin{tabular}{|l|cccc|c|c|c|c|}
\hline \multirow{2}{*}{ Year } & \multicolumn{4}{|c|}{ Consumption } & \multicolumn{3}{c|}{ Production } \\
\cline { 2 - 9 } & Coal & Crude Oil & $\begin{array}{c}\text { Natural } \\
\text { Gas }\end{array}$ & $\begin{array}{c}\text { Hydro-, Nuclear-, and } \\
\text { Wind Power }\end{array}$ & Coal & $\begin{array}{c}\text { Crude } \\
\text { Oil }\end{array}$ & $\begin{array}{c}\text { Natural } \\
\text { Gas }\end{array}$ & $\begin{array}{c}\text { Hydro-, Nuclear-, } \\
\text { and Wind Power }\end{array}$ \\
\hline 1990 & 76.2 & 16.6 & 2.1 & 5.1 & 74.2 & 19.0 & 2.0 & 4.8 \\
1995 & 74.6 & 17.5 & 1.8 & 6.1 & 75.3 & 16.6 & 1.9 & 6.2 \\
2000 & 69.2 & 22.2 & 2.2 & 6.4 & 73.2 & 17.2 & 2.7 & 6.9 \\
2005 & 70.8 & 19.8 & 2.6 & 6.8 & 77.6 & 12.0 & 3.0 & 7.4 \\
2010 & 68.0 & 19.0 & 4.4 & 8.6 & 76.6 & 9.8 & 4.2 & \\
2017 & 60.4 & 18.8 & 7 & 13.8 & 69.6 & 7.6 & 5.4 & 9.4 \\
\hline
\end{tabular}

Source: China Statistical Yearbook (2018)

\section{Theoretical framework}

Energy infrastructure, through the efficient ways of its utilization, plays an essential role in sustainable economic growth and in attracting foreign firms through different channels (Haider, Adil, 2019; Khan et al. 2020). Previous literature shows that energy efficiency is a crucial component of economic development (Akbar et al. 2020), which is only possible if robust energy infrastructure is in place. Energy sector can positively induce the productivity, efficiency, and effectiveness of firms operating across diverse sectors (Rehman et al. 2020). Countries with frequent power shutdowns attract less FDI, because the power cuts interrupt the business and production operations, and ultimately waste the precious time.

Activities and processes involved in agriculture, industry, and services are affected by energy consumption. Foreign firms choose those countries as their destination where they find well-developed energy infrastructure. The more energy consumption means improved productivity. Previous literature shows the pros and cons of using energy as a factor of production. The adverse effects of energy consumption stem from a lack of proper arrangement to control greenhouse gases and $\mathrm{CO}_{2}$ emissions.

Information and communication technology (ICT) can leapfrog the productivity of firms through the information flow (Gholami, Lee, and Heshmati 2006), which is not possible without proper energy resources and infrastructure in the host economies. The argument is justified that such facilities enable firms to reduce time and distance costs. The presence of energy infrastructure, in host economies, can enhance the impact of spillovers originate from MNEs (multinational enterprises). Similarly, energy infrastructure bridges diverse communities, especially through ICT, connected with FDI's activities to contribute positively to economic development.

Similarly, transportation plays a vital role in trade and investments. Energy consumption affects the performance of transportation. The efficient transportation system reduces cost and time. Foreign firms choose those countries with proper transport infrastructure to reduce the additional costs for delayed deliveries, etc. Hence, indirectly energy usage affects the FDI inflows into the host economies.

Energy infrastructure is like an amenity that helps in reducing the cost of production. Hence, it is believed to have relatively more influence on vertical FDI though it also has an impact on horizontal FDI. The amenities are composed of oil \& gas pipelines, electric power distribution, and transmission, storage, etc., which are essential for MNEs to achieve productivity targets and competitiveness. Therefore, infrastructure in the energy sector helps to maximize profit and reduce the cost of doing business for multinational corporations. In the absence of energy infrastructure, the MNEs may incur additional costs and results in reluctance in investments (Erenburg 1993). 


\section{ENTREPRENEURSHIP AND SUSTAINABILITY ISSUES}

ISSN 2345-0282 (online) http://jssidoi.org/jesi/

2020 Volume 8 Number 1 (September)

http://doi.org/10.9770/jesi.2020.8.1(16)

No proper arrangement for greenhouse gases and $\mathrm{CO}_{2}$ emissions can lead to deter foreign investors from entering the host countries. So, the environmental factors also determine the location choice for FDI. Moreover, to reduce the hazards from greenhouse gas emissions, the firms incur additional production costs. The improper safety measures in using energy can affect workers' health and additional costs incur to cure the disease. Nowadays scientific community is engaged in finding renewable and sustainable energy resources, which can reduce the footprints of carbon resulting from the industrial production process. Therefore, countries are investing in renewable energies to reduce their dependence on fossil fuels, etc. The measures can lead to higher energy efficiency and lower energy intensity. These measure may enhance the FDI inflows. Therefore, countries with higher energy efficiency attract more foreign firms.

\section{Data and analytical framework}

\subsection{Data}

The fundamental concern of our study is to show the energy and FDI relationship. The study is based on time series annual data from 1988 to 2017. We rely on the data by Donaubauer et al. (2016). The authors used the unobserved component model (UCM) to construct an index about energy infrastructure. Moreover, the authors used electric power consumption and production (both variables are measured in per capita terms). To measure the reliability and quality of the national electrical power supply, the authors used data on electric power transmission and distribution losses (as a percentage of output). These data run from 1990 to 2010. Following Cooray et al. (2017), we fill in the missing data points up until 2017, by interpolating the data. Control variables are selected, keeping in view the broad review of the literature. FDI is affected by institutional quality (Shah, Ahmad, and Ahmed 2016), trade openness (Iamsiraroj and Ulubaşoğlu 2015), and domestic investment.

The data about institutional quality is obtained from the International Country Risk Guide (ICRG) database. The dataset contains several indices (bureaucratic quality, democratic accountability, the rule of law, investment profile, corruption, and government stability) prepared from the multidimensional sub-datasets. (Buchanan, Le, and Rishi 2012; Globerman and Shapiro 2002) argue that it is not possible to include all the individual aspects of institutional quality in a single regression equation, because they are correlated with each other. Moreover, it is not a good approach for policy concern to include a single aspect of institutional quality in a regression equation and ignoring other aspects of it. Some dataset contains time-invariant indicators, so the indices are developed to make it feasible. For the construction of index and to determine the weight to the indicators regarding various dimensions of institutional quality, the technique of principal component analysis (PCA) is used.

Trade share percent of GDP is used as a proxy for trade openness. Gross fixed capital formation (\% of GDP) is used as a proxy for domestic investment. The data about trade openness and domestic investment is extracted from World Bank (2018).

The descriptive statistics, given in Table 2, show the measure of central tendency and variability of the data. In this regard, we report the mean, median, standard deviation, minimum, and maximum. The mean and median values of primary FDI are close to each other, with the standard deviation is 0.17 , which shows that the data is more scattered. Stability implies that China attracted more FDI in the manufacturing and services sectors. This implies that the macroeconomic environment affects FDI, which may arise due to open-door policies, energy consumption, and production. However, the energy infrastructure shows more variability with the standard deviation is 0.13 . Moreover, all variables follow a normal distribution, according to the Jarque-Bera (JB) test of normality. 
ENTREPRENEURSHIP AND SUSTAINABILITY ISSUES

ISSN 2345-0282 (online) http://jssidoi.org/jesi/

2020 Volume 8 Number 1 (September)

http://doi.org/10.9770/jesi.2020.8.1(16)

Table 2. Descriptive statistics

\begin{tabular}{|l|l|lllllll|}
\hline Variables & Notation & Mean & Median & Max. & Min. & SD & JQ & Prob. \\
\hline FDI (\% share in GDP) & FDI & 1.61 & 1.65 & 1.86 & 1.14 & 0.17 & 6.20 & 0.05 \\
Energy consumption & EC & 0.93 & 0.90 & 1.13 & 0.73 & 0.13 & 2.66 & 0.26 \\
Institutional quality & IQ & 0.95 & 1.13 & 1.39 & -0.29 & 0.45 & 4.45 & 0.11 \\
Trade share in GDP (\%) & TO & 2.62 & 2.61 & 2.82 & 2.40 & 0.12 & 0.66 & 0.72 \\
$\begin{array}{l}\text { Domestic investment share in GDP } \\
(\%)\end{array}$ & DI & 2.58 & 2.60 & 2.67 & 2.41 & 0.07 & 2.46 & 0.29 \\
\hline
\end{tabular}

Note. One is being added to actual values. SD and JQ represent standard deviation and Jarque-Bera statistics.

\subsection{Analytical framework}

In this study, we apply the autoregressive distributive (ARDL) technique of cointegration, developed by Pesaran et al. (2001). There are several advantages to use the ARDL approach. First, the method is applicable irrespective of the order of integration of variables, i.e., $\mathrm{I}(0), 1(1), 1(1,0)$. If the variables are $\mathrm{I}(2)$ or above, then the F-statistics is not invalid (Ouattara 2006). Second, ARDL is applicable in case some of the regressors are endogenous (Odhiambo 2009). Third, the method is effective even in the case of small samples (Ghatak and Siddiki 2001). In the case of small samples, the method is better than Johansen and Juselius (Johansen 1991), Engle \& Granger (Engle and Granger 2015), and Phillips and Hansen (Phillips and Hansen 1990). Another advantage of using ARDL is that it overcomes the problems resulting from series with unit-roots, and the unrestricted error correction model (UECM) seems to take satisfactory lags that captures the data generating process in a general-to-specific framework of specification (Kinkyo, Matsubayashi, and Hamori 2013). We aim to investigate the causal relationship between sectoral FDI and infrastructure across different specifications.

Before the estimation of the empirical results, it is imperative to determine the order of integration. In this regard, we use the Augmented Dicky Fuller (ADF) test. We also apply the Phillips- Perron (PP) test to get robust results. Moreover, we also apply the Zivot-Andrews breakpoint unit root test to avoid misleading and biased results (Muhammad Atif Khan et al. 2020). We follow Ayala and Triguero (2017) and apply Baum's modified methodology for unit root testing against the alternative of trend stationarity with a shift in time trend, shift in mean, and a shift in both slope and intercept.

The next step is to apply the ARDL bounding testing model of cointegration. The bound test F-statistics are obtained that will show us whether cointegration exists or not. If the F-statistic value is higher than the upper bound, then there is cointegration. Similarly, the values of the F-statistic below the lower bound value indicate no cointegration. While the F-statistic value between the upper and lower bound indicate inconclusive region.

To investigate the relationship between infrastructure and foreign direct investment, we can formulate the unrestricted error correction model (ECM) as the following:

$$
\begin{aligned}
& \Delta F D I_{t}=\alpha_{0 f d i}+\sum_{i=1}^{p} \psi_{i f d i} \Delta F D I_{t-i}+\sum_{i=1}^{p} \rho_{i f d i} \Delta E C_{t-i}+\sum_{i=1}^{p} \phi_{i f d i} \Delta I Q_{t-i}+\lambda_{1 f d i} F D I_{t-1}+\lambda_{2 f d i} E C_{t-1}+\lambda_{3 f d i} I Q_{t-1} \\
& +\mu_{1 t}------E q u a t i o n(1)
\end{aligned}
$$




$$
\begin{aligned}
& \Delta E C_{t}=\alpha_{0 e c}+\sum_{i=1}^{p} \psi_{i e c} \Delta E C_{t-i}+\sum_{i=1}^{p} \phi_{i e c} \Delta F D I_{t-i}+\sum_{i=1}^{p} \rho_{i e c} \Delta I Q_{t-i}+\lambda_{1 e c} E C_{t-1}+\lambda_{2 e c} F D I_{t-1}+\lambda_{3 e c} I Q_{t-1} \\
& +\mu_{2 t}-----E q u a t i o n(2) \\
& \Delta F D I_{t}=\alpha_{0 f d i}+\sum_{i=1}^{p} \psi_{i f d i} \Delta F D I_{t-i}+\sum_{i=1}^{p} \rho_{i f d i} \Delta E C_{t-i}+\sum_{i=1}^{p} \phi_{i f d i} \Delta I Q_{t-i}+\sum_{i=1}^{p} \delta_{i f d i} \Delta T O_{t-i}+\lambda_{1 f d i} F D I_{t-1}+\lambda_{2 f d i} E C_{t-1} \\
& +\lambda_{3 f d i} I Q_{t-1}+\lambda_{4 f d i} T O_{t-1}+\mu_{3 t}-----E q u a t i o n(3) \\
& \Delta E C_{t}=\alpha_{0 e c}+\sum_{i=1}^{p} \psi_{i e c} \Delta E C_{t-i}+\sum_{i=1}^{p} \phi_{i e c} \Delta F D I_{t-i}+\sum_{i=1}^{p} \rho_{i e c} \Delta I Q_{t-i}+\sum_{i=1}^{p} \delta_{i e c} \Delta T O_{t-i}+\lambda_{\text {lec }} E C_{t-1}+\lambda_{2 e c} F D I_{t-1} \\
& +\lambda_{3 e c} I Q_{t-1}+\lambda_{4 e c} T O_{t-1}+\mu_{4 t}------E q u a t i o n(4) \\
& \Delta F D I_{t}=\alpha_{0 f d i}+\sum_{i=1}^{p} \psi_{i f d i} \Delta F D I_{t-i}+\sum_{i=1}^{p} \rho_{i f d i} \Delta E C_{t-i}+\sum_{i=1}^{p} \phi_{i f d i} \Delta I Q_{t-i}+\sum_{i=1}^{p} \delta_{i f d i} \Delta T O_{t-i}+\sum_{i=1}^{p} \rho_{i f d i} \Delta D I_{t-i}+\lambda_{1 f d i} F D I_{t-1} \\
& +\lambda_{2 f d i} E C_{t-1}+\lambda_{3 f d i} I Q_{t-1}+\lambda_{4 f d i} T O_{t-1}+\lambda_{5 f d i} D I_{t-1}+\mu_{5 t}------E q u a t i o n(5) \\
& \Delta E C_{t}=\alpha_{0 e c}+\sum_{i=1}^{p} \psi_{i e c} \Delta E C_{t-i}+\sum_{i=1}^{p} \phi_{i e c} \Delta F D I_{t-i}+\sum_{i=1}^{p} \rho_{i e c} \Delta I Q_{t-i}+\sum_{i=1}^{p} \delta_{i e c} \Delta T O_{t-i}+\sum_{i=1}^{p} \rho_{i e c} \Delta D I_{t-i} \\
& +\lambda_{1 e c} E C_{t-1}+\lambda_{2 e c} F D I_{t-1}+\lambda_{3 e c} I Q_{t-1}+\lambda_{4 e c} T O_{t-1}+\lambda_{5 e c} D I_{t-1}+\mu_{6 t}------E q u a t i o n(6)
\end{aligned}
$$

In Eq. (1), (3), and (5), the dependent variable is FDI. Similarly, the dependent variable in the Eq. (2), (4), and (6), is represented by EC. Institutional quality, trade openness, and domestic investment are used as controlled variables for various specifications. The subscript $t$ is the time dimension. ARDL technique is applied to the model for identifying the long-run and short-run dynamics.

Pesaran et al. (2001) provided upper and lower bound critical values. However, the values are applicable for large samples. In the case of small samples, the decision based on the Pesaran et al. (2001) critical values can mislead the estimation results (Herzer 2010). Therefore, we rely on the critical values provided by Narayan (2005), which apply to small sample sizes ranging from 30 to 80 observations. If the computed F-statistic falls above the upper value bound, the null is rejected, indicating cointegration. If the computed F-statistic falls below the lower bound, the null hypothesis of no cointegration is accepted. In contrast, if the computed F-statistic falls within the bounds, the inference would be inconclusive.

The establishment of a long-run relationship means that there must be at least unidirectional causality among the underlying variables (Narayan and Smyth 2005). Moreover, the long-run relationship is only a necessary but not a sufficient condition for the causal relationship among the variables (Morley 2006; Khan et al. 2019; Khan, Chaudhary, and Latif 2020).

If the long-run relationship exists (which is a necessary condition for cointegration but not a sufficient condition), then under the VECM environment, Granger causality test shows long-run and short-run causality for the two variables. Under the VAR framework, the traditional Granger causality test can produce ambiguous results; therefore, under the VECM framework, the following is its improved version. 


$$
\begin{aligned}
& \Delta F D I_{t}=\alpha_{0 f d i}+\sum_{i=1}^{p} \psi_{i f d i} \Delta F D I_{t-i}+\sum_{i=1}^{p} \rho_{i f f i} \Delta E C_{t-i}+\sum_{i=1}^{p} \phi_{i f d i} \Delta I Q_{t-i}+\Omega_{1} E C T_{t-1}+\mu_{7 t}------E q u a t i o n(7) \\
& \Delta E C_{t}=\alpha_{0 e c}+\sum_{i=1}^{p} \psi_{i e c} \Delta E C_{t-i}+\sum_{i=1}^{p} \rho_{i e c} \Delta F D I_{t-i}+\sum_{i=1}^{p} \phi_{i e c} I Q_{t-i}+\Omega_{2} E C T_{t-1}+\mu_{8 t}------E q u a t i o n(8) \\
& \Delta F D I_{t}=\alpha_{0 f d i}+\sum_{i=1}^{p} \psi_{i f d i} \Delta F D I_{t-i}+\sum_{i=1}^{p} \rho_{i f d i} \Delta E C_{t-i}+\sum_{i=1}^{p} \phi_{i f d i} \Delta I Q_{t-i}+\sum_{i=1}^{p} \delta_{i f d i} \Delta T O_{t-i}+\Omega_{3} E C T_{t-1} \\
& +\mu_{9 t}=--E q u a t i o n(9) \\
& \Delta E C_{t}=\alpha_{0 e c}+\sum_{i=1}^{p} \psi_{i e c} \Delta E C_{t-i}+\sum_{i=1}^{p} \rho_{i e c} \Delta F D I_{t-i}+\sum_{i=1}^{p} \phi_{i e c} \Delta I Q_{t-i}+\sum_{i=1}^{p} \delta_{i e c} \Delta T O_{t-i}+\Omega_{4} E C T_{t-1} \\
& +\mu_{10 t}=-----E q u a t i o n(10) \\
& \Delta F D I_{t}=\alpha_{0 f d i}+\sum_{i=1}^{p} \psi_{i f d i} \Delta F D I_{t-i}+\sum_{i=1}^{p} \rho_{i f f i} \Delta E C_{t-i}+\sum_{i=1}^{p} \phi_{i f f i} \Delta I Q_{t-i}+\sum_{i=1}^{p} \delta_{i f d i} \Delta T O_{t-i}+\sum_{i=1}^{p} \delta_{i f d i} \Delta D I_{t-i}+\Omega_{5} E C T_{t-1} \\
& +\mu_{11 t}=-----E q u a t i o n(11) \\
& \Delta E C_{t}=\alpha_{0 e c}+\sum_{i=1}^{p} \psi_{i e c} \Delta E C_{t-i}+\sum_{i=1}^{p} \rho_{i e c} \Delta F D I_{t-i}+\sum_{i=1}^{p} \phi_{i e c} \Delta I Q_{t-i}+\sum_{i=1}^{p} \delta_{i e c} \Delta T O_{t-i}+\sum_{i=1}^{p} \delta_{i e c} \Delta D I_{t-i}+\Omega_{6} E C T_{t-1}
\end{aligned}
$$$$
+\mu_{12 t}------ \text { Equation(12) }
$$

To reach in long-run equilibrium for the variables EC and FDI; ECTs (error correction term) are the speed of adjustment. The significant value of F-statistics determines the short-run causality. The causality is determined by

\begin{tabular}{|c|c|c|c|c|c|c|c|c|c|c|}
\hline \multirow{2}{*}{ Variable } & \multicolumn{2}{|c|}{$\mathrm{ADF}$} & \multicolumn{2}{|c|}{ Phillips- Perron } & \multicolumn{6}{|c|}{ Zivot-Andrews } \\
\hline & $\mathrm{I}(0)$ & $\mathrm{I}(1)$ & $\mathrm{I}(0)$ & $\mathrm{I}(1)$ & $\mathrm{Zd}$ & Break & $\mathrm{Zt}$ & Break & $\mathrm{Zdt}$ & Break \\
\hline FDI & -3.003 & $-4.32 * *$ & $-3.62 * *$ & $-4.26 * *$ & -3.111 & 2014 & $-5.173 * * *$ & 1994 & -4.106 & 2013 \\
\hline $\mathrm{EC}$ & $-3.495^{*}$ & $-7.38 * * *$ & $-3.57 *$ & $-7.26 * * *$ & -3.986 & 1995 & -4.087 & 2000 & $-4.832 *$ & 1999 \\
\hline IQ & -1.853 & $-5.22 * * *$ & $-3.35 *$ & $-5.49 * * *$ & -3.723 & 1995 & -3.832 & 1999 & $-4.782 *$ & 2001 \\
\hline TO & -0.75 & $-3.58 *$ & -0.974 & $-3.62 * *$ & -4.504 & 2013 & -4.148 & 2011 & $-4.912 *$ & 2013 \\
\hline DI & $-3.83 * *$ & $-3.71 * *$ & -2.264 & $-3.52 *$ & -4.497 & 2015 & $-4.717 * *$ & 2014 & $-5.839 * * *$ & 2011 \\
\hline
\end{tabular}
the F-statistics to test the joint significance of all the lagged first differences of independent variables (Ali and Wang 2018; Zhang 2001; Lee 2010; Khan et al. 2019; Khan, Ilyas, and Hashmi 2018). Whereas the significant value of t-statistics for $\mathrm{ECT}_{\mathrm{t}-1}$ indicates the long-run causality.

\section{Results}

Table 3 shows the unit-root results for the underlying variables of the study. The results indicate that all the variables are stationary at the level and $1^{\text {st }}$ difference. Moreover, the response variable is integrated of order I(1), which satisfied the precondition specified by Pesaran et al., (2001).

Table 3. Unit root and stationary test results.

Note. ${ }^{*} \mathrm{p}<0.10, * * \mathrm{p}<0.05, * * * \mathrm{p}<0.01$. ADF and PP tests include intercept and trend. The ZA tests are the minimum Dicky-Fuller statistics with one structural break in intercept $(\mathrm{Zd})$, trend $(\mathrm{Zt})$, and both intercept and trend (Zdt). Break indicates the year when minimum DF statistic is obtained.

The significant F-statistics of the estimated ARDL bound test in Table 4 for FDI as a dependent variable reject the null of no cointegration, which indicates a stable long-run relationship between FDI and EC. However, when we 
use EC as a dependent variable, then the values of F-statistic are below the lower bound; hence found no cointegration.

Table 4. ARDL bounds test results.

\begin{tabular}{|c|c|c|c|c|c|c|c|c|}
\hline \multirow{3}{*}{ Specifications } & \multirow{3}{*}{ Max lag } & \multirow{3}{*}{$\begin{array}{c}\text { F- } \\
\text { statistics }\end{array}$} & \multicolumn{6}{|c|}{ Critical values } \\
\hline & & & \multicolumn{2}{|c|}{$1 \%$} & \multicolumn{2}{|c|}{$5 \%$} & \multicolumn{2}{|l|}{$10 \%$} \\
\hline & & & $I(0)$ & $I(1)$ & $I(0)$ & $I(1)$ & $I(0)$ & $I(1)$ \\
\hline \multicolumn{9}{|l|}{ Panel A. EC to FDI } \\
\hline Model 1. FDI /(EC, IQ, DM) & $(4,0,4,4)$ & $9.804 * *$ & 5.2 & 6.3 & 3.5 & 4.4 & 2.9 & 3.7 \\
\hline Model 2.FDI/(EC, IQ, DM ,TO) & $(4,4,3,4,4)$ & $42.20 * * *$ & 4.6 & 6.0 & 3.3 & 4.3 & 2.7 & 3.6 \\
\hline Model 3.FDI/( EC, IQ, DM, TO, DI) & $(3,3,3,3,3,3)$ & $6.00 * * *$ & 4.3 & 5.8 & 3.1 & 4.2 & 2.5 & 3.6 \\
\hline \multicolumn{9}{|l|}{ Panel B. FDI to EC } \\
\hline Model 1.EC/(FDI, IQ, DM) & $(4,3,4,2)$ & 2.509 & 5.2 & 6.3 & 3.5 & 4.4 & 2.9 & 3.7 \\
\hline Model 2. EC /(FDI, IQ, DM, TO) & $(4,4,4,4,3)$ & 2.69 & 4.6 & 6.0 & 3.3 & 4.3 & 2.7 & 3.6 \\
\hline $\begin{array}{l}\text { Model 3. EC /( FDI, IQ, DM, TO, } \\
\text { DI) }\end{array}$ & $(3,1,3,2,3,3)$ & 1.67 & 4.3 & 5.8 & 3.1 & 4.2 & 2.5 & 3.6 \\
\hline
\end{tabular}

Notes: The first letter outside the brackets denotes dependent variables. The symbol $* * *, * *$, and * indicate significance at 99\%, 95\% and 90\% confidence level, respectively. The null hypothesis of no cointegration is tested with F-test, critical values are taken from Narayan (2005) for case II: restricted intercept and no trend. Lag selection is based on the AIC. DM resspresents a dummy variable used to control structural breaks.

Johansen multivariate cointegration test is conducted to check for robustness. Table 5 reports the results. We see that there are three cointegrating vectors which validate the presence of a long-run relationship between the variables, which indicate the ARDL results are robust and reliable.

Table 5.The Johansen cointegration analysis.

\begin{tabular}{|l|ll|}
\hline Hypothesis & Trace statistic & Max. Eigenvalue \\
\hline $\mathrm{R}=0$ & $129.27 * * *$ & $63.324 * * *$ \\
$\mathrm{R} \leq 1$ & $65.95 * * *$ & $33.99 * * *$ \\
$\mathrm{R} \leq 2$ & $31.952 * *$ & $20.188^{*}$ \\
$\mathrm{R} \leq 3$ & 11.764 & 11.646 \\
$\mathrm{R} \leq 4$ & 0.1176 & 0.1176 \\
\hline
\end{tabular}

Note. $* \mathrm{p}<0.10, * * \mathrm{p}<0.05, * * * \mathrm{p}<0.01$

After identifying the long-run relationship between EC and FDI, we estimate the long-run effects. Table 6 shows the estimation results. Here we see that the coefficients of EC are significant and positive. The results imply that energy infrastructure positively impacts foreign investment. Similarly, the coefficients of control variables are according to our expectations and economic theories. The diagnostic results show that the inclusion of additional variables improves the overall goodness of fit. The Lagrange Multiplier (LM) test shows that our models are not suffering from the autocorrelation. Autoregressive conditional heteroskedasticity $(\mathrm{ARCH})$ reveals that we have no heteroskedasticity problem. Ramsey reset tests indicate that our models are correctly specified. Similarly, the Jarque-Bera test shows that residuals of the models are normally distributed. 
Table 6. Results on Long-Run Effect.

\begin{tabular}{|c|c|c|c|}
\hline Variables & Mode 1 & Mode 2 & Mode 3 \\
\hline $\mathrm{EC}$ & $\begin{array}{l}0.319 * * * \\
(0.03)\end{array}$ & $\begin{array}{l}0.534 * * * \\
(0.04)\end{array}$ & $\begin{array}{l}0.405^{*} \\
(0.15)\end{array}$ \\
\hline Institutional quality & $\begin{array}{l}0.429^{*} \\
(0.18)\end{array}$ & $\begin{array}{l}0.305 \\
(0.17)\end{array}$ & $\begin{array}{l}1.095 \\
(0.89)\end{array}$ \\
\hline Trade openness & & $\begin{array}{l}1.110 \\
(0.31)\end{array}$ & $\begin{array}{l}2.718^{* *} \\
(0.59)\end{array}$ \\
\hline Domestic investment & & & $\begin{array}{l}3.152 \\
(1.65)\end{array}$ \\
\hline Dummy & $\begin{array}{l}-0.709 * * * \\
(0.18)\end{array}$ & $\begin{array}{l}0.990 * \\
(0.53)\end{array}$ & $\begin{array}{l}0.018 \\
(0.12)\end{array}$ \\
\hline Constant & $\begin{array}{l}4.646^{* * * *} \\
(0.87)\end{array}$ & $\begin{array}{l}4.095 \\
(0.84)\end{array}$ & $\begin{array}{l}2.857 \\
(4.44)\end{array}$ \\
\hline \multicolumn{4}{|l|}{$\underline{\text { Diagnostic results }}$} \\
\hline F-statistics & $13.324 * * *$ & $17.33 * * *$ & $9.317 * *$ \\
\hline LM test (chi-square) & $\begin{array}{l}2.189 \\
(0.199)\end{array}$ & $\begin{array}{l}1.426 \\
(0.23)\end{array}$ & $\begin{array}{l}2.032 \\
(0.154)\end{array}$ \\
\hline ARCH test (chi-square) & $\begin{array}{l}1.437 \\
(0.230)\end{array}$ & $\begin{array}{l}0.603 \\
(0.43)\end{array}$ & $\begin{array}{l}2.563 \\
(0.109)\end{array}$ \\
\hline Ramsey reset (F-stat.) & $\begin{array}{l}3.98 \\
(0.143)\end{array}$ & $\begin{array}{l}4.20 \\
(0.10)\end{array}$ & $\begin{array}{l}3.83 \\
(0.355)\end{array}$ \\
\hline Jarque-Bera (chi-square) & $\begin{array}{l}3.133 \\
(0.208)\end{array}$ & $\begin{array}{l}0.182 \\
(0.913)\end{array}$ & $\begin{array}{l}2.79 \\
(0.25)\end{array}$ \\
\hline
\end{tabular}

Note. $* \mathrm{p}<0.10, * * \mathrm{p}<0.05, * * * \mathrm{p}<0.01$. Standard errors are in parenthesis. The numbers in the parenthesis in the diagnostic panel are the p-values. Models are stable.

Table 7 reports the short- and long-run causality, which indicates that there is a unidirectional causal relationship between EC and FDI. The values of ECTs are significant and negative in the upper panel where we used FDI as a dependent; however, in the lower panel, the values ECTs are insignificant. The short-run F-statistic is significant in the model where FDI is dependent. For the rest of the models, the short-run F-statistics are insignificant. Hence, except model 1, we are unable to see short-run causality.

Table 7. Granger causality results.

\begin{tabular}{|c|c|c|}
\hline Specifications & Short Run (F-Stat) & Long-run $\mathrm{ECT}_{\mathrm{t}-1}$ \\
\hline Model 1. FDI /(EC, IQ, DM) & $8.05 * * *$ & $-0.43 * *$ \\
\hline Model 2.FDI/(EC, IQ, DM, TO) & 21.56 & $-0.57 * * *$ \\
\hline Model 3.FDI/( EC, IQ, DM, TO, DI) & 2.75 & $-0.69 * * *$ \\
\hline \multicolumn{3}{|l|}{ FDI to EC } \\
\hline Model 1.EC/(FDI, IQ, DM) & 1.95 & -0.13 \\
\hline Model 2. EC /(FDI, IQ, DM, TO) & 1.69 & -0.20 \\
\hline Model 3. EC /( FDI, IQ, DM, TO, DI) & 2.66 & -0.39 \\
\hline
\end{tabular}

Note. $* \mathrm{p}<0.10, * * \mathrm{p}<0.05, * * * \mathrm{p}<0.01$. 
ENTREPRENEURSHIP AND SUSTAINABILITY ISSUES

ISSN 2345-0282 (online) http://jssidoi.org/jesi/

2020 Volume 8 Number 1 (September)

http://doi.org/10.9770/jesi.2020.8.1(16)

The summary results of the short-run and long-run causality between the EC and foreign direct investment are shown in Table 8.

Table 8. Long-run and short-run causality.

\begin{tabular}{|l|l|l|}
\hline \multirow{2}{*}{ Specifications } & \multicolumn{1}{|c|}{ Short-run causality } & Fong-run causality \\
\cline { 2 - 3 } & \multicolumn{2}{|c|}{ FDI \& EC } \\
\hline Model 1. & Unidirectional & Unidirectional \\
Model 2. & No causality & Unidirectional \\
Model 3. & No causality & Unidirectional \\
\hline
\end{tabular}

Overall the results show that there exist unidirectional long-run causal relationships between energy and FDI. Our study confirms the hypothesis that energy consumption and its infrastructure positively attract foreign investors; the reverse impact does not hold. The presence of energy infrastructure boosts FDI inflow in China. However, we find that FDI does not explain energy. The findings are similar to (Dong, Shao, and Zhang 2019). It means that developing countries, like China, with low restrictions on greenhouse emissions, attract more FDI (Pollution paradise" hypothesis). On the other, we see that there is no technological effect of FDI on reducing the energy intensity in China. The possible explanations of the results are that substantial Chinese investments in the energy sector and its consumption are growing enormously and become more influential. Market reforms and greater transparency are making energy projects attractive in China. In this regard, the 'I Squared Capital' wastewater treatment industry is a prominent figure in the energy sector of China.

\section{Conclusions}

China's integration into the world economy, and maintaining its rapid economic growth, demand more energy with a prominent concern of reducing carbon footprints. Coal is the leading energy source that drives more than half of the Chinese economy. Similarly, China imports around 60 percent of the oil that it consumes. It is the world largest oil importer as about 2014, but it has been doing a lot to make sure that its energy consumption across a range of fuels. To take into account the issues of greenhouse emissions and to maintain sustainable growth, China is making conscious efforts to increase the proportionality of clean energy in its energy mix. Similarly, the massive inflow of foreign direct investment (FDI) in China is a marvelous phenomenon the world sees during the last three decades. The opening up policy made China the fourth largest destination for foreign investments.

The relationship between FDI and energy infrastructure, though important for policy concerns, is not studied. Previous literature mainly focused on the emission and growth aspects of energy consumption but ignored the foreign investment perspective. Previous studies focus on the impact of energy consumption on economic growth and other macroeconomic variables. Moreover, the majority of the previous literature discusses the environmental effects of energy. Similarly, more studies focused on cross-country analysis. We, for the first time, contribute the existing literature by examining the relationship between FDI and energy infrastructure on a country level to have in-depth insight.

Moreover, the previous studies are based on a single specification and a single equation. The earlier literature ignores the institutional quality, which may affect the FDI and energy relationship in developing countries like China. We contribute the literature by using the ARDL and VECM approaches in a multi-specification framework, which means that we add additional variables in the baseline model. Similarly, we contribute to the earlier literature by adding an important variable, i.e., institutional quality. 


\section{ENTREPRENEURSHIP AND SUSTAINABILITY ISSUES}

ISSN 2345-0282 (online) http://jssidoi.org/jesi/ 2020 Volume 8 Number 1 (September) http://doi.org/10.9770/jesi.2020.8.1(16)

We find a long-run relationship between energy and growth. The causality analysis shows that there is a unidirectional causal relationship running from energy to FDI. We find that energy contributes positively to FDI inflows. The Johansen multivariate cointegration test validates the ARDL results. The inclusions of control variables (FDI, institutional quality, domestic investment, and trade openness) increase the goodness of fit of the models.

This study carries several policy recommendations. Efforts should be made to enhance alternative means of energy like thermal and solar energy resources to achieve the desired economic outcomes. The current study can be augmented by incorporating a broader set of energy variables into a single index, which will provide more accurate and reliable results. Similarly, future research should be targeted at a provincial and sectoral level.

Disclosure statement

The authors reported no potential conflict of interest.

\section{References}

Akbar, Usman, József Popp, Hameed Khan, Muhammad Asif Khan, and Judit Oláh. 2020. "Energy Efficiency in Transportation along with the Belt and Road Countries.” Energies 13 (10). https://doi.org/10.3390/en13102607

Ali, Usman, and Jian Jun Wang. 2018. "Does Outbound Foreign Direct Investment Crowd Out Domestic Investment in China? Evidence from Time Series Analysis.” Global Economic Review 47 (4): 419-33. https://doi.org/10.1080/1226508X.2018.1492431

Azémar, Céline, and Rodolphe Desbordes. 2013. "External Financial Dependence and FDI Responsiveness to Corporate Tax Rates." Applied Economics Letters 20 (16): 1472-76. https://doi.org/10.1080/13504851.2013.826859

Bevan, Alan A., and Saul Estrin. 2004. "The Determinants of Foreign Direct Investment into European Transition Economies.” Journal of Comparative Economics 32 (4): 775-87. https://doi.org/10.1016/j.jce.2004.08.006

Bevir, Mark, and Stephen R. Hurt. 2012. "World Development Indicators." Encyclopedia of Governance. https://doi.org/10.4135/9781412952613.n571

Bhaumik, Sumon Kumar, and Catherine Yap Co. 2011. "China's Economic Cooperation Related Investment: An Investigation of Its Direction and Some Implications for Outward Investment.” China Economic Review $22 \quad$ (1): $75-87$. https://doi.org/10.1016/j.chieco.2010.09.002

Bilgili, Faik, Nadide Sevil Halici Tülüce, and Ibrahim Doğan. 2012. "The Determinants of FDI in Turkey: A Markov Regime-Switching Approach." Economic Modelling 29 (4): 1161-69. https://doi.org/10.1016/j.econmod.2012.04.009

Blonigen, Bruce A., and Ronald B. Davies. 2004. "The Effects of Bilateral Tax Treaties on U.S. FDI Activity." International Tax and Public Finance 11 (5): 601-22. https://doi.org/10.1023/B:ITAX.0000036693.32618.00

Blonigen, Bruce A., Christopher J. Ellis, and Dietrich Fausten. 2005. "Industrial Groupings and Foreign Direct Investment." Journal of International Economics 65 (1): 75-91. https://doi.org/10.1016/j.jinteco.2003.12.003

Buchanan, Bonnie G., Quan V. Le, and Meenakshi Rishi. 2012. "Foreign Direct Investment and Institutional Quality: Some Empirical Evidence.” International Review of Financial Analysis 21: 81-89. https://doi.org/10.1016/j.irfa.2011.10.001

Buckley, Peter J., L. Jeremy Clegg, Adam R. Cross, Xin Liu, Hinrich Voss, and Ping Zheng. 2007. "The Determinants of Chinese Outward Foreign Direct Investment.” Journal of International Business Studies 38 (4): 499-518. https://doi.org/10.1057/palgrave.jibs.8400277

Cañón, Luis Ayala, and ángela Triguero Cano. 2017. "Economic Downturns, Endogenous Government Policy and Welfare Caseloads." Hacienda Publica Espanola 220 (1): 107-36. https://doi.org/10.7866/HPE-RPE.17.1.4

Chakrabarti, A. 2001. "The Determinants of Foreign Direct Investment: Sensitivity Analyses of Cross-Country Regressions.” Kyklos 54 (1): 89-114. https://doi.org/10.1111/1467-6435.00142 


\section{ENTREPRENEURSHIP AND SUSTAINABILITY ISSUES}

ISSN 2345-0282 (online) http://jssidoi.org/jesi/ 2020 Volume 8 Number 1 (September) http://doi.org/10.9770/jesi.2020.8.1(16)

Cooray, Arusha, Ratbek Dzhumashev, and Friedrich Schneider. 2017. "How Does Corruption Affect Public Debt? An Empirical Analysis." World Development 90: 115-27. https://doi.org/10.1016/j.worlddev.2016.08.020

Deng, Ping. 2004. "Outward Investment by Chinese MNCs: Motivations and Implications." Business Horizons 47 (3): 8-16. https://doi.org/10.1016/S0007-6813(04)00023-0

Dharmapala, Dhammika, and James R. Hines. 2009. "Which Countries Become Tax Havens?” Journal of Public Economics 93 (9-10): 1058-68. https://doi.org/10.1016/j.jpubeco.2009.07.005

Donaubauer, Julian, Birgit E. Meyer, and Peter Nunnenkamp. 2016. “A New Global Index of Infrastructure: Construction, Rankings and Applications." World Economy 39 (2): 236-59. https://doi.org/10.1111/twec.12290

Dong, Yixuan, Shuai Shao, and Yan Zhang. 2019. "Does FDI Have Energy-Saving Spillover Effect in China? A Perspective of EnergyBiased Technical Change.” Journal of Cleaner Production 234: 436-50. https://doi.org/10.1016/j.jclepro.2019.06.133

Doytch, Nadia, and Mesut Eren. 2012. "Institutional Determinants of Sectoral FDI in Eastern European and Central Asian Countries: The Role of Investment Climate and Democracy." Emerging Markets Finance and Trade 48 (SUPPL.4): 14-32. https://doi.org/10.2753/REE1540-496X4806S402

Engle, Robert F., and Clive W.J. Granger. 2015. "Co-Integration and Error Correction: Representation, Estimation, and Testing." Applied Econometrics 39 (3): 107-35. https://doi.org/10.2307/1913236

Erenburg, S. J. 1993. "The Real Effects of Public Investment on Private Investment." Applied Economics 25 (6): $831-37$. https://doi.org/10.1080/00036849300000137

Flores, Ricardo G., and Ruth V. Aguilera. 2007. "Globalization and Location Choice: An Analysis of US Multinational Firms in 1980 and 2000.” Journal of International Business Studies 38 (7): 1187-1210. https://doi.org/10.1057/palgrave.jibs.8400307

Ghatak, S., and J. U. Siddiki. 2001. "The Use of the ARDL Approach in Estimating Virtual Exchange Rates in India." Journal of Applied Statistics 28 (5): 573-83. https://doi.org/10.1080/02664760120047906

Gholami, Roghieh, Sang Yong Tom Lee, and Almas Heshmati. 2006. "The Causal Relationship between Information and Communication Technology and Foreign Direct Investment.” World Economy 29 (1): 43-62. https://doi.org/10.1111/j.1467-9701.2006.00757.x

Globerman, Steven, and Daniel Shapiro. 2002. "Global Foreign Direct Investment Flows: The Role of Governance Infrastructure." World Development 30 (11): 1899-1919. https://doi.org/10.1016/S0305-750X(02)00110-9

Haider, S., \& Adil, M. H. (2019). "Does financial development and trade openness enhance industrial energy consumption? A sustainable developmental perspective" Management of Environmental Quality: An International Journal, 30 (6): 1297-1313.

https://www.emerald.com/insight/content/doi/10.1108/MEQ-03-2019-0060/full/html

Herzer, Dierk. 2010. "Outward FDI and Economic Growth.” Journal of Economic Studies 37 (5): 476-94. https://doi.org/10.1108/01443581011075424

Iamsiraroj, Sasi, and Mehmet Ali Ulubaşoğlu. 2015. "Foreign Direct Investment and Economic Growth: A Real Relationship or Wishful Thinking?” Economic Modelling 51: 200-213. https://doi.org/10.1016/j.econmod.2015.08.009

Islam, Mollah Aminul, Muhammad Asif Khan, József Popp, Wlodzimierz Sroka, and Judit Oláh. 2020. "Financial Development and Foreign Direct Investment_-The Moderating Role of Quality Institutions.” Sustainability 12 (9): 3556. https://doi.org/10.3390/su12093556

Johansen, Soren. 1991. "Estimation and Hypothesis Testing of Cointegration Vectors in Gaussian Vector Autoregressive Models." Econometrica 59 (6): 1551. https://doi.org/10.2307/2938278

Kang, Yuanfei, and Fuming Jiang. 2012. "FDI Location Choice of Chinese Multinationals in East and Southeast Asia: Traditional Economic Factors and Institutional Perspective.” Journal of World Business 47 (1): 45-53. https://doi.org/10.1016/j.jwb.2010.10.019

Khan, Hameed, Umair Khan, Li Jun Jiang, and Muhamad Asif Khan. 2020. "Impact of Infrastructure on Economic Growth in South Asia: Evidence from Pooled Mean Group Estimation.” The Electricity Journal 33 (5): 106735. https://doi.org/https://doi.org/10.1016/j.tej.2020.106735 


\section{ENTREPRENEURSHIP AND SUSTAINABILITY ISSUES}

ISSN 2345-0282 (online) http://jssidoi.org/jesi/ 2020 Volume 8 Number 1 (September)

http://doi.org/10.9770/jesi.2020.8.1(16)

Khan, Hameed, Umair Khan, and Muhammad Asif Khan. 2020. "Causal Nexus between Economic Complexity and FDI: Empirical Evidence from Time Series Analysis.” The Chinese Economy. https://doi.org/10.1080/10971475.2020.1730554

Khan, Muhammad Asif, Ghulam Mujtaba Chaudhary, and Khalid Latif. 2020. "How Consumer Confidence, Corruption and Credit Rating Effect the Exchange Rate: Emerging Market Perspective." Journal of Accounting and Finance in Emerging Economies 6 (2): $367-79$. https://doi.org/https://doi.org/10.26710/jafee.v6i2.1109

Khan, Muhammad Asif, Raja Muhammad Ahsan Ilyas, and Shujahat Haider Hashmi. 2018. "Cointegration between Institutional Quality and Stock Market Development.” NUML International Journal of Business \& Management 13(2): 90-103.

Khan, Muhammad Asif, Muhammad Atif Khan, Mohamued Elyas Abdulahi, Idrees Liaqat, and Sayyed Sadaqat Hussain Shah. 2019. "Institutional Quality and Financial Development: The United States Perspective." Journal of Multinational Financial Management 49 (March): 67-80. https://doi.org/10.1016/j.mulfin.2019.01.001

Kinkyo, Takuji, Yoichi Matsubayashi, and Shigeyuki Hamori. 2013. Financial Globalization and Regionalism in East Asia. Financial Globalization and Regionalism in East Asia. Edward Elgar Publishing. https://doi.org/10.4324/9781315857800

Lee, Chew Ging. 2010. "Outward Foreign Direct Investment and Economic Growth: Evidence from Japan." Global Economic Review 39 (3): 317-26. https://doi.org/10.1080/1226508X.2010.513143

Morley, Bruce. 2006. "Causality between Economic Growth and Immigration: An ARDL Bounds Testing Approach.” Economics Letters 90 (1): 72-76. https://doi.org/10.1016/j.econlet.2005.07.008

Khan, Muhammad Atif, Muhammad Asif Khan, Kishwar Ali, József Popp, and Judit Oláh. 2020. "Natural Resource Rent and Finance: The Moderation Role of Institutions.” Sustainability 12 (9): 3897. https://doi.org/10.3390/su12093897.ze

Nagano, Mamoru. 2013. "Similarities and Differences among Cross-Border M\&A and Greenfield FDI Determinants: Evidence from Asia and Oceania.” Emerging Markets Review 16: 100-118. https://doi.org/10.1016/j.ememar.2013.04.001

Narayan, Paresh Kumar. 2005. “The Saving and Investment Nexus for China: Evidence from Cointegration Tests.” Applied Economics 37 (17): 1979-90. https://doi.org/10.1080/00036840500278103

Narayan, Paresh Kumar, and Russell Smyth. 2005. "Electricity Consumption, Employment and Real Income in Australia Evidence from Multivariate Granger Causality Tests.” Energy Policy 33 (9): 1109-16. https://doi.org/10.1016/j.enpol.2003.11.010

Odhiambo, Nicholas M. 2009. "Energy Consumption and Economic Growth Nexus in Tanzania: An ARDL Bounds Testing Approach." Energy Policy 37 (2): 617-22. https://doi.org/10.1016/j.enpol.2008.09.077

Ouattara, Bazoumana. 2006. "Aid, Debt and Fiscal Policies in Senegal." Journal of International Development 18 (8): $1105-22$. https://doi.org/10.1002/jid.1282

Pesaran, M. Hashem, Yongcheol Shin, and Richard J. Smith. 2001. "Bounds Testing Approaches to the Analysis of Level Relationships." Journal of Applied Econometrics 16 (3): 289-326. https://doi.org/10.1002/jae.616

Phillips, Peter C. B., and Bruce E. Hansen. 1990. "Statistical Inference in Instrumental Variables Regression with I(1) Processes." The Review of Economic Studies 57 (1): 99. https://doi.org/10.2307/2297545

Rehman, Faheem Ur, Muhammad Asif Khan, Muhammad Atif Khan, Khansa Pervaiz, and Idrees Liaqat. 2020. "The Causal, Linear and Nonlinear Nexus between Sectoral FDI and Infrastructure in Pakistan: Using a New Global Infrastructure Index." Research in International Business and Finance 52 (November): 101-29. https://doi.org/10.1016/j.ribaf.2019.101129

Shah, Syed Hasanat, Mohsin Hasnain Ahmad, and Qazi Masood Ahmed. 2016. "The Nexus between Sectoral FDI and Institutional Quality: Empirical Evidence from Pakistan.” Applied Economics 48 (17): 1591-1601. https://doi.org/10.1080/00036846.2015.1103039

Tihanyi, Laszlo, and Anthony S. Roath. 2002. "Technology Transfer and Institutional Development in Central and Eastern Europe." Journal of World Business 37 (3): 188-98. https://doi.org/10.1016/S1090-9516(02)00077-9

UNCTAD. 2019. World Investment Report 2019. https://unctad.org/en/PublicationsLibrary/wir2019_en.pdf 


\section{ENTREPRENEURSHIP AND SUSTAINABILITY ISSUES}

ISSN 2345-0282 (online) http://jssidoi.org/jesi/ 2020 Volume 8 Number 1 (September) http://doi.org/10.9770/jesi.2020.8.1(16)

Wei, Shang Jin. 2000. “How Taxing Is Corruption on International Investors?” Review of Economics and Statistics 82 (1): 1-11. https://doi.org/10.1162/003465300558533

Wheeler, David, and Ashoka Mody. 1992. "International Investment Location Decisions. The Case of U.S. Firms.” Journal of International Economics 33 (1-2): 57-76. https://doi.org/10.1016/0022-1996(92)90050-T

Zhang, Kevin Honglin. 2001. "Does Foreign Direct Investment Promote Economic Growth? Evidence from East Asia and Latin America." Contemporary Economic Policy 19 (2): 175-85. https://doi.org/10.1111/j.1465-7287.2001.tb00059.x

Dr. Hameed KHAN (Doctoral in Economics from Jilin University, Changchun, China). Currently, he is working at Kohat University of Science \& Technology, Kohat, Pakistan. His research interests consist of MNCs, Finance, and Institutions.

ORCID ID: 0000-0003-1775-0687

Dr. Imrab SHAHEEN (Ph.D. in Management Sciences) is serving as Assistant Professor, Department of Public Administration, University of Kotli, AJ\&K, Pakistan. Her research interests include Women Empowerment, Entrepreneurship, Microfinance, SMEs management.

ORCID ID: 0000-0002-4587-1307

Mr. Masood AHMED is expected to defend his doctoral candidate in Public Policy at Lee Kuan Yew School of Public Policy, National University of Singapore, Singapore by July 2020. He is affiliated as a lecturer with the Department of Public Administration, University of Kotli, AJ\&K, Pakistan. His research interest is revolving around includes; Water Policy, Governance, Public Finance, and Institutions. ORCID ID: 0000-0001-5089-7109

Mr. EImin BAKHSHALIEV is a Ph.D student of International Relations at Jilin University, Changchun, China. His ressearch interest include political economy, migration, and international investments.

ORCID ID: 0000-0002-3131-7954

Mr. Hashmat Ullah KHAN is a Ph.D student of International Relations at Jilin University, Changchun, China. His ressearch interest include international political economy, regional affairs, and international relations.

ORCID ID: 0000-0002-8172-9252

Dr. Asif KABIR (Ph.D. in Communication and Information System, Chongqing University P.R. China). Dr. Kabir is serving as Assistant Professor, Department of CS\&IT, University of Kotli, AJ\&K, Pakistan. His research interests include; Mobile wireless communication network, Energy Efficiency, Green Communication, and Big Data among others.

ORCID ID: 0000-0001-7743-5131

Register for an ORCID ID:

https://orcid.org/register

Copyright (C) 2020 by author(s) and VsI Entrepreneurship and Sustainability Center

This work is licensed under the Creative Commons Attribution International License (CC BY).

http://creativecommons.org/licenses/by/4.0/

c) (i) Open Access 